\title{
Water Restriction Affects Germination and Initial Sunflower Development
}

Oscar Mitsuo Yamashita (Corresponding Author), Danillo de La Queyferr Goncalves, Marco Antonio Camillo de Carvalho, Rivanildo Dallacort, Ricardo Adriano Felito, Aureane Cristina Teixeira Ferreira, Adriano Maltezo da Rocha

UNEMAT, Av.Perimetral Rogério Silva 4390, Alta Floresta, Mato Grosso, Brazil. E-mail: yama@unemat.br

Received: Dec. 23, 2019 Accepted: Feb. 16, $2020 \quad$ Published: Feb. 25, 2020

doi:10.5296/jas.v8i3.16050

URL: https://doi.org/10.5296/jas.v8i3.16050

\begin{abstract}
Sunflower is a crop of great economic interest both nationally and internationally, due to its use especially in oil production. However, factors such as water restriction are commonly found in growing areas and exert a negative influence on the productive performance of the crop, especially in critical periods, such as the germination and initial development of the seedlings. Thus, the objective of this study was to evaluate the germinate behavior of seeds of sunflower cultivars as a function of lower osmotic potentials. The experiment was installed in a completely randomized design, in a $3 \times 5$ factorial scheme, three sunflower cultivars (Charrua, Nussol and Olisiun 4) and five osmotic potentials (0, -0.2, -0.4, -0.8, -1.2 MPa) with 3 replicates. For the study, solutions of polyethylene glycol (PEG 6000) were repaired. Rolls of paper towels were moistened with the concentrations and later kept in a germination chamber at $25{ }^{\circ} \mathrm{C}$, where they remained for ten days. First counts (4th day) and total counts (10th day) were performed, and the germination rate (\%) was verified. In addition, in the last evaluation, aerial and root length, green mass and dry mass of seedlings were determined. Based on the results obtained it can be verified that in osmotic potential higher than $-0.8 \mathrm{MPa}$, no germination occurred. Nussol germinated more in more negative concentrations, with a germination rate of $90 \%$, differing from the cultivars Charrua and Olisiun 4, which, in larger potentials, reached only $30 \%$ of germination.
\end{abstract}

Keywords: Helianthus annus, Cultivars, PEG6000, Osmotic potentials

\section{Introduction}

The sunflower has stood out nationally and internationally for being a multipurpose plant and from which almost everything is used. The pivoting root system allows for the cycling of nutrients in the soil, the rods can be used in the manufacture of acoustic insulation material, 
the leaves and the stems promote good green fertilization, and can reach up to 5 tons per hectare of dry mass. The fertilized flowers give rise to the achenes fruits that contain the seeds rich in oil (47\%) of excellent nutritional quality (Queiroz, 2006).

The sowing season is fundamental to the success and attainment of high yields in sunflower cultivation, as in any other crop. The ideal sowing moment is one in which the different stages of growth and development of the plant have their demands satisfied by the environment, reducing risks, losses and increasing the chances of securing a good harvest.

The seed has attributes of genetic, physical, physiological and sanitary qualities, which gives it the guarantee of a high agronomic performance, which is the fundamental base of the success for a technically well-established crop. Seeds, to be considered of high quality, must have good physiological and sanitary characteristics, such as germination rate, vigor and sanity, as well as guarantee of physical and varietal purities, besides not containing weed seeds (Krzyzanowski et al., 2004).

These factors are mainly responsible for the performance of the seed in the field, culminating in the establishment of the plant population required by the cultivar, a fundamental aspect that contributes to the achievement of high levels of productivity (Kappes et al., 2010). In the field, one of the most important aspects to be observed is the seed performance during the germination process and the subsequent emergence of the seedlings. High quality seeds result in strong, vigorous, well-developed seedlings that settle in the different edaphic and climatic conditions, with greater speed of emergence and of plant development, culminating in the fast closing of the lines (Carvalho and Nakagawa, 2000), which results also in the efficient control of weeds (Oliveira Jr. et al., 2011).

Water stress is the main determinant of sunflower yield, much in part to its effect on leaf area. The lack of water in the tissues disfavors the leaf expansion and leads to this reduced leaf area. This is the main defense mechanism of plants against lack of water, since with smaller leaf area there will be less losses due to evapotranspiration. The lack of soil moisture in the sowing-emergence phase can prolong its duration and reduce the initial population of plants and, consequently, productivity (Embrapa, 2016).

Research related to water stress is developed with different substances to simulate water stress conditions, but polyethylene glycol (PEG) has been used more commonly, because it is a chemically inert, non-toxic and non-electrolytic osmotic agent. This product is available in commercial formulations with different molecular weights $(4,000 ; 6,000 ; 8,000 ; 12,000$ and 20,000), 6,000 being the most used because it does not penetrate the cells due to its high molecular weight (Martins et al., 2014).

The objective of this work was to verify the behavior of sunflower seeds under different osmotic potentials, identifying the potentials from which one has water restriction.

\section{Material and Methods}

The experiment was conducted at the Laboratory of Seed Technology and Weed Science (LaSeM) of the State University of Mato Grosso (UNEMAT), Alta Floresta Campus, Brazil. 
To verify the effect of osmotic potential of polyethylene glycol (PEG 6000) and tolerance to water stress of the seeds of sunflower cultivars, a germinate and initial development of the seedlings was carried out. The experiment was organized in a completely randomized design, in a $3 \times 5$ factorial scheme consisting of 3 cultivars (Charrua, Nussol and Olision 4) and 5 osmotic potentials $(0.0 ;-0.2 ;-0.4 ;-0.8 ;-1.2 \mathrm{MPa})$, for a total of 15 treatments, with 3 replicates.

In order to calculate the amount of PEG 6000, the equation proposed by Michel and Kaufmann (1973) was used:

$\Psi$ os $=-\left(1.18 \times 10^{-2}\right) \mathrm{C}-\left(1.18 \times 10^{-4}\right) \mathrm{C} 2+\left(2.67 \times 10^{-4}\right) \mathrm{CT}+\left(8.39 \times 10^{-7}\right) \mathrm{C}^{2} \mathrm{~T}$

Being that $\psi \mathrm{os}=$ osmotic potential (bar); $\mathrm{C}=$ concentration (grams of PEG 6000 per $\mathrm{kg}$ of distilled water); $\mathrm{T}=$ temperature $\left({ }^{\circ} \mathrm{C}\right)$, being considered $25^{\circ} \mathrm{C}$.

In conducting the research, the procedures described in the Rules for Seed Analysis (Brasil, 2009) were followed. For each treatment, 50 seeds were seeded in germitest paper, in paper roll format, after being moistened with the solutions with their respective osmotic potentials, which (rolls) were later kept in a germinating chamber type BOD, the constant temperature of $25^{\circ} \mathrm{C}$ for 10 days.

The evaluations started on the fourth day after assembling the test, being evaluated the percentage of seeds that presented root protrusion with extension greater than or equal to $2 \mathrm{~mm}$. The following parameters were analyzed: seed germination, seedling length, root length and green mass weight and dry seedling mass.

The root length, aerial part determination and green mass weight were evaluated on the fourth day and the tenth day. Dry mass was determined by collecting the seedlings that germinated on the last day of the experiment and then dried in a greenhouse at $65{ }^{\circ} \mathrm{C}$ for 72 hours and weighed in a precision scale $(0.01 \mathrm{~g})$.

The data, after analysis of the variance homoscedasticity, were submitted to the analysis of variance by the test F. Having significance, the averages of the qualitative factors were compared by the Tukey test at $5 \%$ of probability and the quantitative factors by the regression analysis (in these cases, graphs were made), using statistical software Sisvar (Ferreira, 2011).

\section{Results}

\subsection{Germination Rate}

There was significance for the isolated factors and the interaction of these (cultivars* concentrations) in all evaluated variables. There was a reduction in the germination rate in all cultivars, this reduction occurred as the osmotic potentials became more negative (Table 1). 
Table 1. First germination count (\%) of three sunflower cultivars submitted to water restriction

\begin{tabular}{lccc}
\hline & \multicolumn{3}{c}{ Cultivars } \\
\cline { 2 - 4 } Potentials & Nussol & Charrua & Olisiun 4 \\
\cline { 2 - 4 } - 0.0 & $99.3 \mathrm{~A}$ & $61.3 \mathrm{~B}$ & $72.6 \mathrm{~B}$ \\
$\mathbf{- 0 . 2}$ & $96.0 \mathrm{~A}$ & $80.7 \mathrm{~B}$ & $76.0 \mathrm{~B}$ \\
$\mathbf{- ~ 0 . 4}$ & $86.7 \mathrm{~A}$ & $76.0 \mathrm{~B}$ & $82.0 \mathrm{~B}$ \\
$\mathbf{- 0 . 8}$ & $5.3 \mathrm{~B}$ & $26.0 \mathrm{~A}$ & $34.7 \mathrm{~A}$ \\
$\mathbf{- 1 . 2}$ & $0.0 \mathrm{~A}$ & $0.0 \mathrm{~A}$ & $0.0 \mathrm{~A}$ \\
\hline $\mathbf{C V}(\%)$ & & 14.23 & \\
\hline
\end{tabular}

Averages followed by the same capital letter in the row and lowercase in the column are not different from each other by the Tukey test at $5 \%$ probability.

From -0.4 MPa, there was a significant reduction in the germination of the cultivars studied. No germination was observed in the lowest studied potential, independent of the cultivar. Nussol cultivar showed to be less tolerant, since there was a reduction of $94 \%$ between -0.4 and -0.8 MPa. The cultivars Charrua and Olisiun 4, in these same concentrations, presented reduction of 66 and $58 \%$, respectively (Figure 1).

It was observed that the cultivar Nussol showed a higher germination rate in relation to the other cultivars studied, until the potential of $-0.4 \mathrm{MPa}$, showing a clear superiority of at least $15 \%$ when compared to Charrua and Olisiun 4 , in the first count of germination.

For the total germinated seeds, this difference remained only for the cultivar Nussol in relation to Olisiun 4 in the potential of $-0.2 \mathrm{MPa}$. The greater sensitivity of Nussol from -0.8 MPa remained in this variable (Table 2). 
Table 2. Total germination (\%) of sunflower cultivars submitted to water restriction

\begin{tabular}{lccc}
\hline & & Cultivars & \\
\cline { 2 - 4 } Potentials (MPa) & Nussol & Charrua & Olisiun 4 \\
\cline { 2 - 4 } $\boldsymbol{- 0 . 0}$ & $99.3 \mathrm{~A}$ & $74.6 \mathrm{~B}$ & $74.5 \mathrm{~B}$ \\
$\mathbf{- ~ 0 . 2}$ & $96.7 \mathrm{~A}$ & $85.3 \mathrm{~A}$ & $78.7 \mathrm{~B}$ \\
$\mathbf{- ~ 0 . 4}$ & $92.0 \mathrm{~A}$ & $78.7 \mathrm{~A}$ & $83.3 \mathrm{~A}$ \\
$\mathbf{- ~ 0 . 8}$ & $5.3 \mathrm{~B}$ & $33.3 \mathrm{~A}$ & $44.0 \mathrm{~A}$ \\
$\mathbf{- 1 . 2}$ & $0.0 \mathrm{~A}$ & $0.0 \mathrm{~A}$ & $0.0 \mathrm{~A}$ \\
\hline $\mathbf{C V}(\%)$ & & 15.33 & \\
\hline
\end{tabular}

Means followed by the same capital letter in the row and lowercase in the column do not differ from each other by the Tukey test at $5 \%$ probability. 

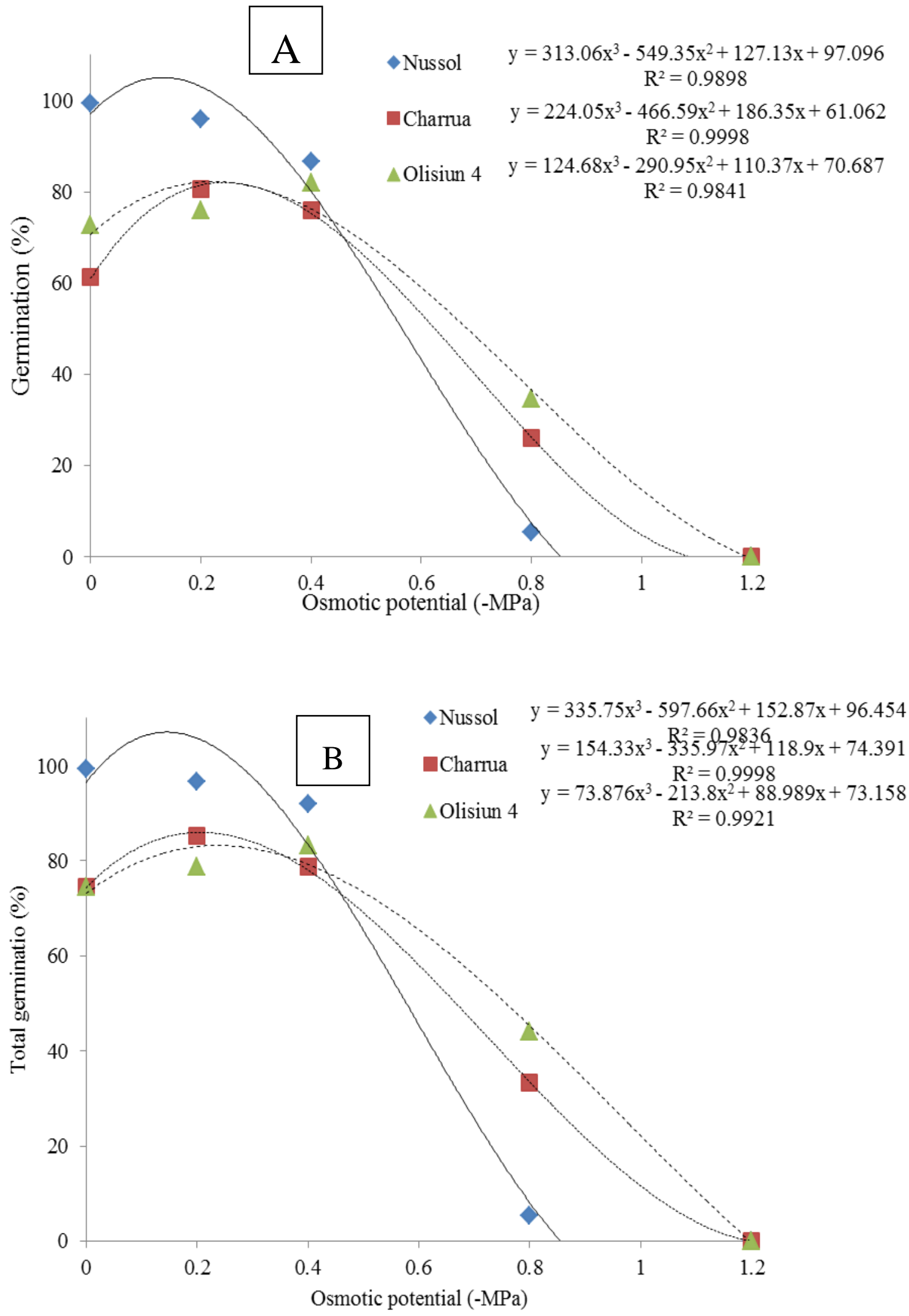

Figure 1. First germination count (A) and Total germination (B) of sunflower cultivars submitted to increasing concentrations of PEG 6000, aiming at water restriction 


\subsection{Length of Aerial Part}

As for shoot length, there was no difference between the cultivars in the first count, only one reduction was verified as the potential decreased (Figure 2). This behavior was maintained in the total air behavior count (Figure 2). In both evaluations, there was a quadratic reduction, and in the potential of $(-1.2 \mathrm{MPa})$, because no germination was verified, the values of these two variables corresponded to zero.
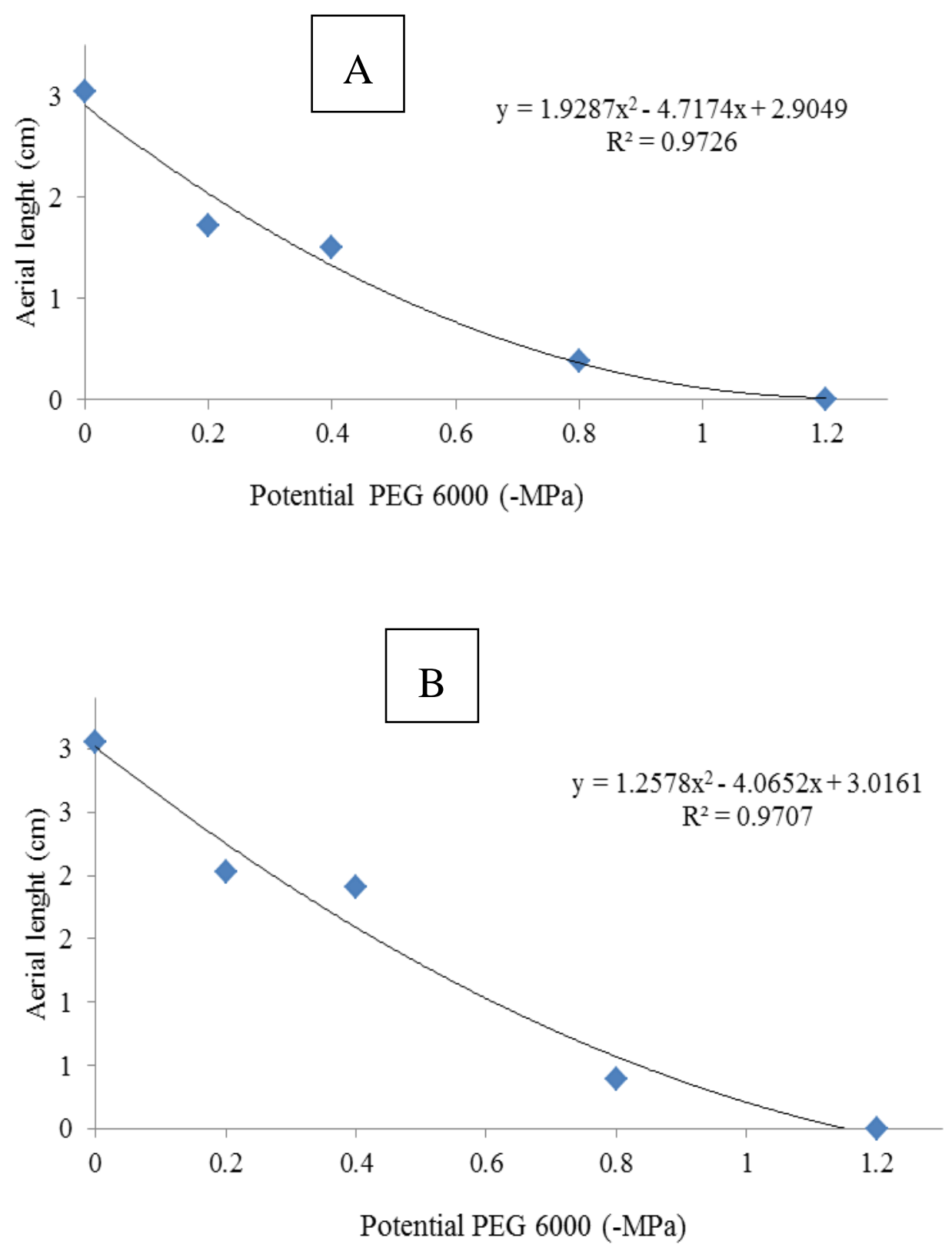

Figure 2. First count of aerial length (A) and Total air length (B) of sunflower seedlings submitted to water restriction

In the control treatment, the air length remained and, with water restriction, there was a 
decrease in the values in this variable, following a quadratic reduction trend. The aerial part began to be affected, not allowing the normal development of this important part of the plant to occur. Thus, at lower potentials the seedlings failed to develop their aerial part and when they tried, the seedlings became abnormal.

At potentials between -0.2 and $-0.4 \mathrm{MPa}$, the seedlings were kept at an average length of 1.5 centimeters. In the potential $-0.6 \mathrm{MPa}$, there was a stoppage in its growth as a consequence of the smaller aerial part.

\subsection{Root Length}

For the root length variable, the potentials -0.2 and $-0.4 \mathrm{MPa}$ were greater than the control potential; and in the potential of -1,2 $\mathrm{MPa}$, that there was no germination occurrence (Figure 3 ). In the first counting and in the total count, the root length at -0.2 and $-0.4 \mathrm{MPa}$, are superior to the other potentials, with length between 4 and 5 centimeters and others with length between 1 and 2 centimeters (Figure 3 ).

There was a significant reduction in root system growth of sunflower cultivars, with no difference between them (Figure 3). As the osmotic potential decreased, root length followed a quadratic reduction trend.

In Table 3, one can see the cultivars that developed more their root system, a defense mechanism thus expanding the roots in search of water, cultivating Nussol and Charrua, were those that had greater capacity to expand their roots, the smaller water deficiency signal the plant diminishes its cellular expansion, and later the closure of the stomata, reducing aerial part and development of the hypocotyl, the plant to work and taking advantage of the night to be able to grow, the cultivar Olisiun 4 has a smaller development, being thus more sensitive to water stress, failing to expand its root system.

Table 3. Root length first count and total count of sunflower cultivars submitted to water restriction
Cultivars
First Root Length
Total Root Length

\begin{tabular}{ccc}
\hline Nussol & $3.43 \mathrm{a}$ & $3.76 \mathrm{a}$ \\
Charrua & $2.45 \mathrm{ab}$ & $2.97 \mathrm{ab}$ \\
Olisiun 4 & $1.55 \mathrm{~b}$ & $1.55 \mathrm{~b}$ \\
\hline CV $(\%)$ & 62.80 & 65.05 \\
\hline
\end{tabular}

Means followed by the same lowercase letter in the column are not different from each other by the Tukey test at $5 \%$ probability. 

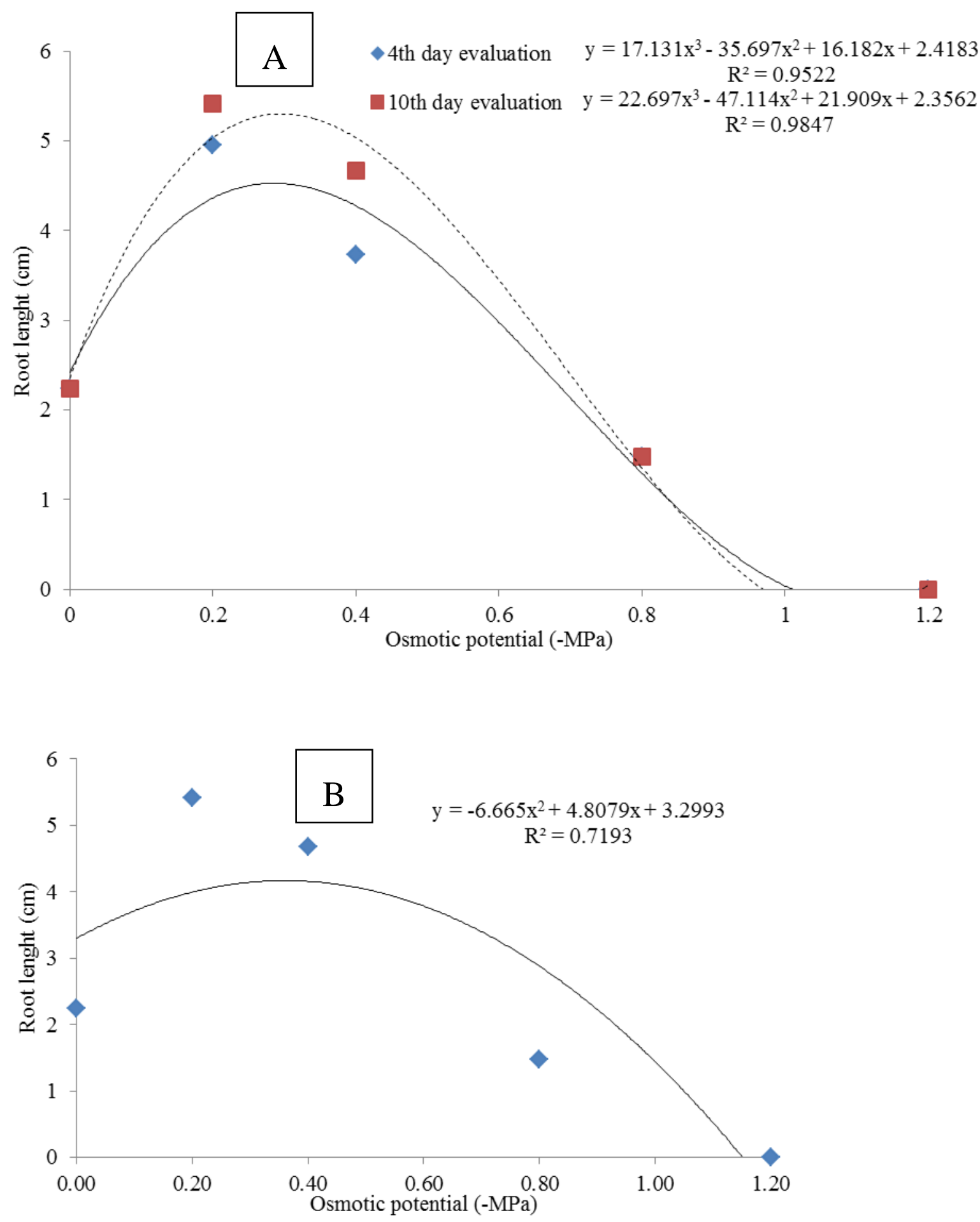

Figure 3. First count of root length (A) and Total root length count (B) of sunflower seedlings subjected to water restriction.

\subsection{Weight of Green Mass and Dry Mass}

Figure 4 show that at the control level there were higher results, reaching $0.25 \mathrm{mg}$, and at concentrations -0.2 and $-0.4 \mathrm{MPa}$, the values reached approximately $0.18 \mathrm{mg}$. Differing from 


\section{Macrothink

the dry weight, values of 0.07 to $0.09 \mathrm{mg}$ were observed in concentrations of -0.2 and -0.4 $\mathrm{MPa}$, while the control level reached values of $0.06 \mathrm{mg}$ (Figure 5).
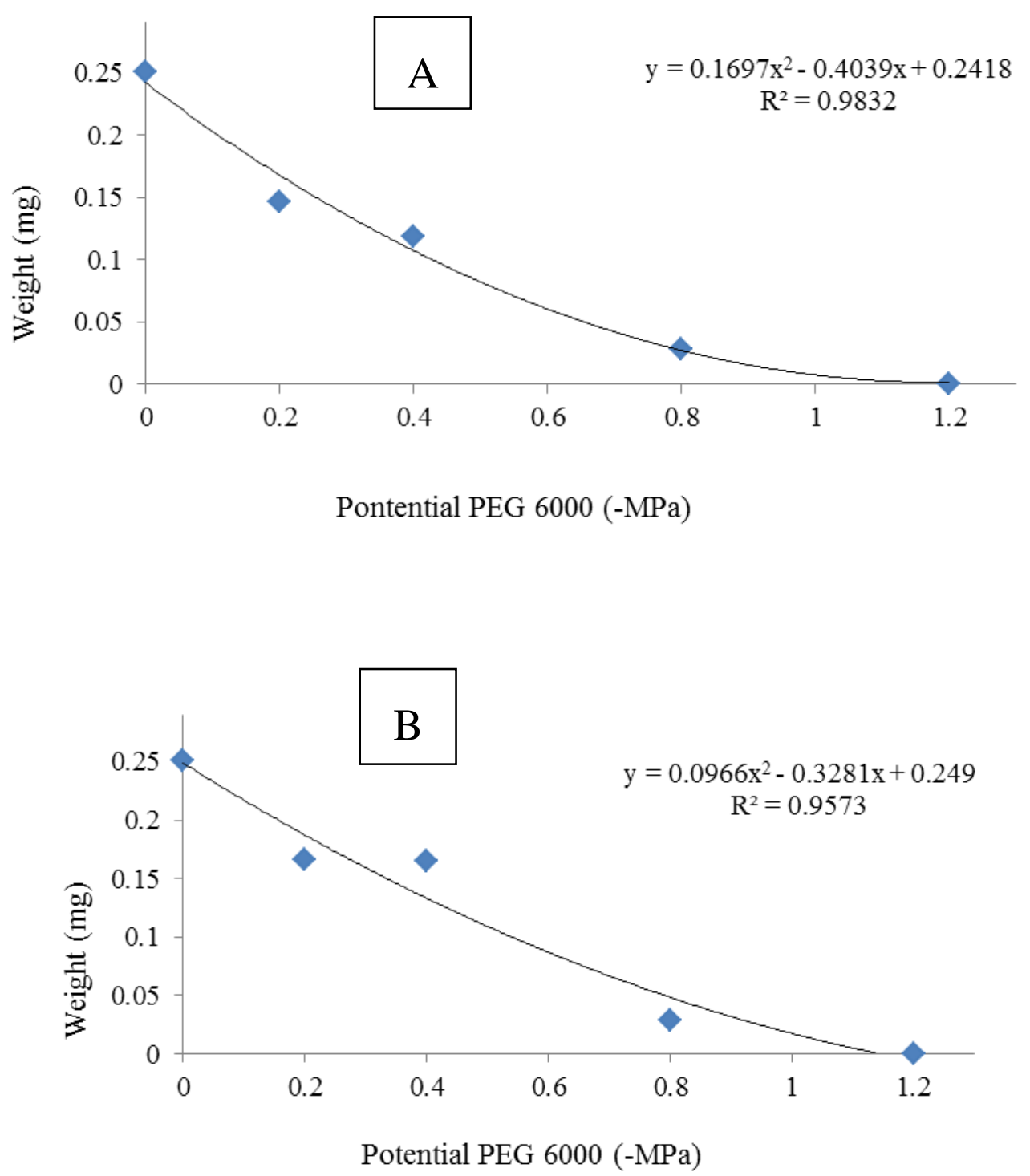

Figure 4. First weight count of green mass (A) and Weight count of total green mass (B) of sunflower seedlings subjected to water restriction

These results allow inferring that the seedlings submitted to low osmotic potential suffered, reducing the accumulation of dry mass of the aerial part, in contrast to the root.

Both green mass and dry mass weight had a decreasing quadratic response as the osmotic potential became more negative.

These results corroborate with those found in the other variables, reinforcing the difficulty in developing sunflower seedlings as water supply was smaller, regardless of cultivar. 

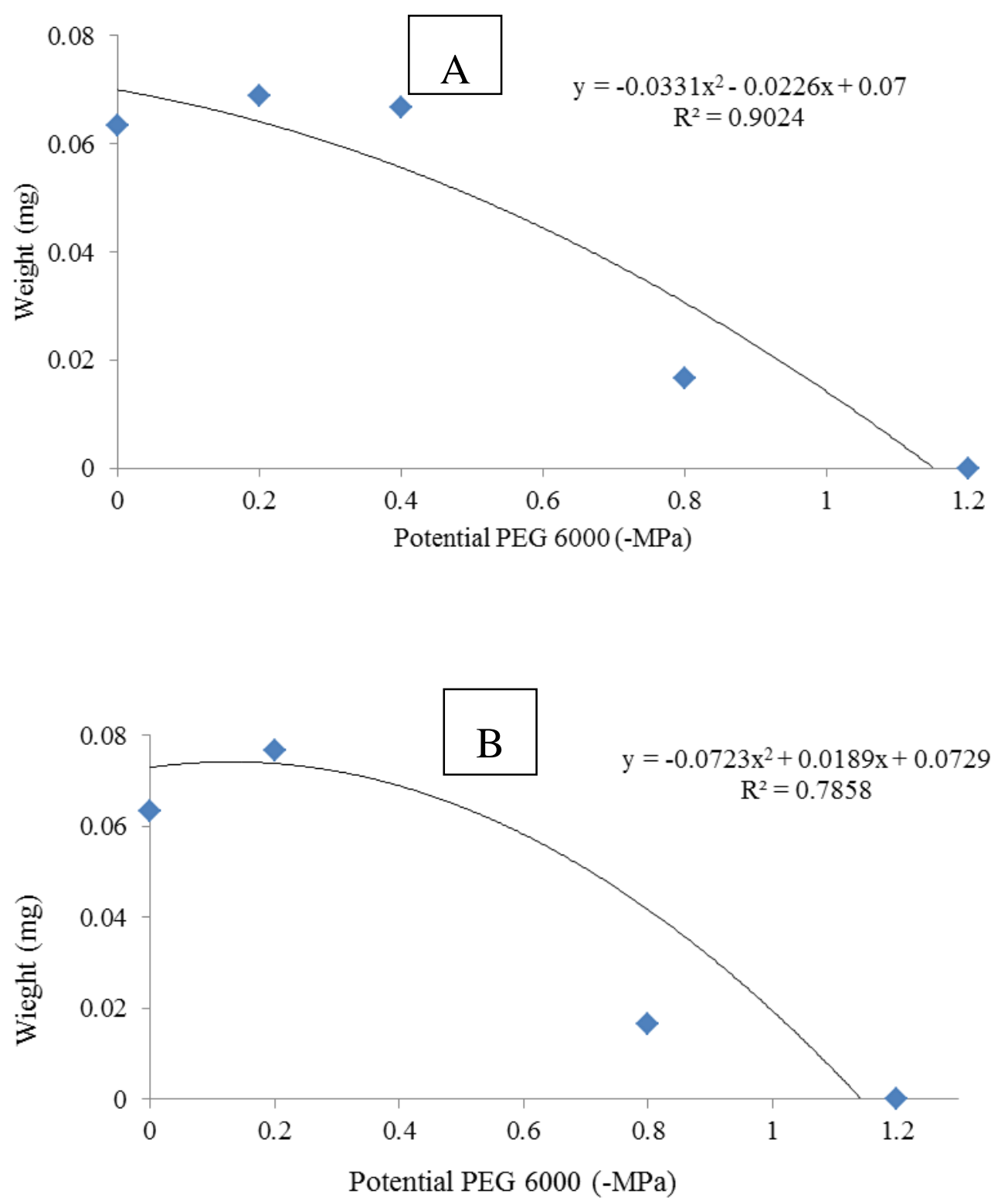

Figure 5. First dry weight count (A) and Total dry weight (B) of sunflower seedlings subjected to water restriction

\section{Discussion}

\subsection{Germination}

Water is the essential element for the activation of different metabolic processes for the seed germination process to occur (Ávila et al., 2007). Research related to seed germination response under simulated stress conditions is important within ecophysiology, being fundamental for the evaluation of the limits and tolerance of survival and adaptation of each species under natural stress conditions (Guedes et al., 2013).

Study by Yamashita et al. (2009) with germination of Emilia sonchifolia seeds submitted to water stress simulated by PEG 6000, observed reductions in seed germination and 
germination speed from -0.1 MPa potential and no germination from -0.4 MPa. Guedes et al. (2013) also found inhibition in vigor of Apeiba tibourbou seeds with the potential of -0.6 $\mathrm{MPa}$ and Melaleuca quinquenervia (Martins et al., 2011), in which osmotic potentials equal to or less than $-0.8 \mathrm{MPa}$, due to $\mathrm{PEG}$ or $\mathrm{NaCl}$ prevented germination, a behavior similar to the results found in the present work.

For Bowdichia virguloides, Silva et al. (2001) report that the germination percentage was drastically reduced from the osmotic potential $-0.5 \mathrm{MPa}$ of PEG 6000, with no germination at lower potentials (-0.9 and -1.1 MPa). Braga et al. (2008) found a reduction in germination percentage of Schizolobium amazonicum seeds in potentials from -0.1 to $-0.5 \mathrm{MPa}$ of PEG 6000 , differing from control.

Similar results with gliricidia were reported by Farias et al. (2009), who also using PEG 6000 as osmotic agent, observed a decrease of approximately $50 \%$ in the osmotic potential of -0.5 $\mathrm{MPa}$ in relation to the absence of water stress, not verifying occurrence of germination in the osmotic potential of -2.0. MPa. A study by Guedes et al. (2013) on raft seeds found that germination was reduced from -0.2 $\mathrm{MPa}$.

Pereira et al. (2014), studying water stresses by PEG and $\mathrm{NaCl}$ solutions in the germination of rape (Raphanus raphanistrum) and stinky (Senna obtusifolia) seeds, found that stress conditions impaired the germination and seed vigor of these species, in which The stress promoted by the PEG solution caused greater negative effects than $\mathrm{NaCl}$ for both species, being the minimum germination limit found in the potential of $-0.4 \mathrm{MPa}$. These results contribute to the research results of Teixeira et al. (2011), in which he evaluated the germination and vigor of crambe (Crambe abyssinica) seeds under PEG 6000 induced water stress with 0.0 to $-1.4 \mathrm{MPa}$ solutions. For the same authors, they found that the reduction of substrate osmotic potential promotes significant reduction in germination and seed vigor of this species.

A possible explanation for this effect is related to the high molecular weight of PEG, which due to its high viscosity and low $\mathrm{O}_{2}$ diffusion rate may compromise the oxygen availability to the seeds during the germination process (Braccini et al., 1996).

The effect caused by water stress is associated with reduced water availability and cellular dehydration, where for each species there is a soil water potential value below which germination does not occur (Maraghni et al., 2010).

Water restriction decreases the speed of metabolic and biochemical processes, delaying or reducing the percentage of seed germination, interfering with embryo imbibition and cell elongation (Bradford, 1990).

According to Santos et al. (1992), the decrease in seed germination under water stress is attributed to the reduction of enzymatic activity, which promotes less meristematic development. However, the ability of seeds of some species to germinate under water stress conditions confers ecological advantages over others that are drought sensitive (Scheidt da Rosa et al., 2005). 


\subsection{Shoot Length}

Shoot length was negatively influenced as water stress intensified, corroborating the study by Carneiro et al. (2011), where there was a reduction in shoot length of sunflower seedlings as the concentration of PEG 6000 was increased, with the lowest values observed at the potential of $-0.8 \mathrm{MPa}$, reducing plant growth by decreasing cell turgidity (Jaleel et al., 2009).

For Abati et al. (2014), the inhibition of airborne seedling growth is mainly due to water restriction to slow the physiological and biochemical processes, impeding the development.

In other cultures, similar behaviors are also found, similar to those obtained by Kappes et al. (2010) where they verified reduction of air length in corn and soybean seedlings submitted to PEG 6000 solution.

As a defense in conditions of lack of water and reduction of air growth, to retain more water in its entirety, the seedling loses leaf area, causing the root part to develop more demand for moist soil. Spollen and Sharp (1991) reported that maize roots can grow at potential levels that inhibit shoot growth. This is advantageous especially for seedling survival when the water supply is limited.

According to Vaz de Melo et al. (2012), seedling shoot length and seedling weight of three popcorn cultivars had the same behavior under water stress, decreasing their values with the increase of water stress caused by the decrease of osmotic potential. The water stress caused by osmotic potentials below $-0.4 \mathrm{MPa}$ caused lower germination speed in popcorn seeds.

Seedling under water stress increases endogenous aba concentration, which would act both by maintaining root growth and inhibiting shoot growth (Spyropoulos, 1986). Water stress can cause reduction in seedling growth by restricting cell wall loosening or reducing the entry of solutes into the embryo under water stress conditions, the same authors observed a low enzyme activity in sucrose degradation, resulting in a decrease in embryo growth.

The first and most sensitive response to water deficit is the reduction of cell turgidity, which leads to decreased growth, since cell division, stretching and differentiation are affected by water deficits. in not-so-severe water deficit conditions, the plant can prevent a reduction in cell turgidity by initiating osmorregulatory measures such as the synthesis of organic compounds and the conversion of starch to soluble carbohydrates, thereby ensuring water inflow and maintenance of cell volume (Larcher, 2000).

\subsection{Root Length}

The lack of water reflected directly on the development of roots and shoots. Commonly, when under water deficit, plants are rehydrated at night as a result of substantial leaf growth during this period (Carvalho and Nakagawa, 2000). According to Hoogenbomm et al. (1987), under water deficit conditions there is greater root expansion due to soil surface drying.

Work by Carneiro et al. (2011), in a study with sunflower seedlings, found that the root length in the potentials of -0.2 and $-0.4 \mathrm{MPa}$ was higher than the control, in PEG 6000 concentration, and this behavior is similar to the results observed in this study. 
These results differ from those observed by Bertagnolli (2003) with lettuce seeds, where water potentials of -0.20 and $-0.40 \mathrm{MPa}$ caused reduction of primary root emission and percentage of seed germination. Water stress reduces water absorption, which causes rapid growth reduction, and a set of metabolic changes that culminate with decreased shoot growth, probably due to the hormones produced by the roots (Munns, 2002).

Research by Kappes et al. (2010), when evaluating water stress on germination and seed vigor of corn hybrids, observed a reduction in root growth as the osmotic potential of the solution decreased.

For Taiz and Zeiger (2009), the first measurable effect of water stress corresponds to the decrease in growth, caused by the reduction of cell expansion that needs adequate turgor potential.

Root length is one of the characteristics that give plants greater tolerance to water deficit, and as water stress can occur increasingly, the contact between the root surface and soil is maximized by root hair emission, with consequent increase surface area and water absorption capacity (Ramos Junior et al., 2013).

When plants are exposed to water stress, various effects are triggered that culminate in different responses. Study conducted by Paixão et al. (2014), evaluating the physiological and biochemical characterization of sunflower genotypes with different tolerance to water stress, found a difference in soluble protein contents, being affected differently by stress, where it was observed increases in soluble protein contents in relation to days that did not suffered water stress.

Proteins are fundamental in all aspects of cellular structure and function, present in all parts of cells. Modifications in their contents can be a major damage to plant growth and development (Coscolin et al., 2011).

The root system of sunflower crop is pivotal, growing faster than the aerial part of the plant at the beginning of development, being formed by a main axis and abundant secondary roots, able to exploit a large volume of soil. Root length develops in greater proportion than air length when water is lacking, and begins to develop. The development of the root system in the deeper layers of the profile enables plants to better exploit soil moisture and fertility, depending on plant morphological and genotypic characteristics (Goldmann et al., 1989).

\subsection{Weight of Green Pasta and Dry Pasta}

All germination processes depend on the fulfillment of the restrictive factors and from this. the deficit water can not only damage the process, but also promote seedling malformation, which will not be able to accumulate mass, affecting its development and later production (Krzyzanowski et al., 2004).

Both the weight of green mass and dry mass were affected by water deficit, reducing the cellular expansion of the seeds, so the green mass did not develop fully. This weight reflects the little water absorbed, the seedling hurry the need to fetch water, so that it can continue the aerial development. Authors report that when the plant begins to feel water deficiency, all its 
water-consuming activities cease so that it can exert more energy into the root system in search of moist soil.

Guedes et al. (2013), observed that the dry mass content of Apeiba tibourbou seedlings was reduced as it restricted water potential, becoming null at -0.8 MPa. The reduction in epicotyl dry mass may have possibly occurred due to the decrease in seed metabolism, due to the lower availability of water for digestion of reserves and translocation of metabolized products (Bewley and Black, 1994).

This reduction is due to the demand for physiological and biological processes or the difficulty of hydrolysis and the mobilization of stored seed reserves (Bewley and Black, 1994).

Guandu plants under water stress showed a marked reduction in shoot dry mass (Muchow et al., 1983). These results are similar to those obtained by Costa et al. (2004) and in Machado Neto et al. (2006) in bean seeds, which as the increase of water stress decreased the dry matter of shoots. Távora and Melo (1991) described that the main mechanisms of the plant to escape the water deficit are root increase and deepening, which may be due to growth (cell elongation) or dry mass gain (growth and thickness of cell walls).

Torres et al. (1999) studying cucumber seeds, noticed the progressive effect on the reduction of dry mass as the potential decreased at the level of $-0.2 \mathrm{MPa}$. For Machado Neto et al. (2006), water deficit can affect plant development by promoting changes in the total number of leaves, leaf emergence rate, leaf expansion and senescence.

According to Smith and Cothren (1999), water stress generally increases the root/shoot ratio in cotton plants, as the shoot is more affected and is a way to reduce the breathable surface.

\section{Conclusion}

The cultivar Nussol has greater tolerance in seed germination to water stress up to $-0.4 \mathrm{MPa}$. From this potential it becomes more sensitive than Charrua and Olisiun 4.

Regardless of cultivar, sunflower seeds have seedling development and mass accumulation impaired by water stress caused by PEG 6000.

\section{Acknowledgement}

The research is financed by State University of Mato Grosso. Thanks to Atlantica Seeds. Thanks to LaSeM/Ceptam/Unemat for the infrastructure for conducting the research. To Researchers Renata Yonaha Zocante and Marcio Takeo Yamashita for technical support.

\section{References}

Abati, J. et al. (2014). Qualidade fisiológica de sementes de trigo tratadas com biorregulador em condições de restrição hídrica. Informativo Abrates, 24, 32-36.

Ávila, M.R. et al. (2007). Influência do estresse hídrico simulado com manitol na germinação de sementes e crescimento de plântulas de canola. Revista Brasileira de Sementes, 29, 98-106. 
Bertagnolli, C.M. (2003). Desempenho de sementes nuas e peletizadas de alface (Lactuca sativa L.) submetidas a estresse hídrico e térmico. Revista Brasileira de Sementes, 25,7-13.

Bewley, J.D. \& Black, M. (1994). Seeds: Physiology of development and germination. (2rd. ed.). New York: Plenum.

Braccini, A.L. (1996). Germinação e vigor de sementes de soja sob estresse hídrico induzido por soluções de cloreto de sódio, manitol e polietilenoglicol. Revista Brasileira de Sementes, 18,10-16.

Bradford, K.J. (1990). Water relations analysis of seed germination rates. Plant Physiology, 94,840-849.

Braga, L.F. et al. (2008). Germinação de sementes de pinho-cuiabano sob deficiência hídrica com diferentes agentes osmóticos. Scientia Forestalis, 36,157-163.

Brasil. (2009). Ministério da Agricultura, Pecuária e Abastecimento. Regras para análise de sementes. Ministério da Agricultura, Pecuária e Abastecimento. Secretaria de Defesa Agropecuária. Brasília, DF: Mapa/ACS.

Carneiro, M.M.L.C. et al. (2011). Atividade antioxidante e viabilidade de sementes de girassol após estresse hídrico e salino. Revista Brasileira de Sementes, 33,752-761.

Carvalho, N.M. \& Nakagawa, J. (2000). Sementes: ciência, tecnologia e produção. (4rd ed.) Funep, Jaboticabal.

Coscolin, R.B.D.S. et al. (2011). Effects of hydric deficiency on gas exchange parameters and metabolism of Eucalyptus grandis clones. Brazilian Journal of Plant Physiology, 23,255-262.

Costa, P.R. et al. (2004). Estresse hídrico induzido por manitol em sementes de soja de diferentes tamanhos. Revista Brasileira de Sementes, 26,105-113.

Embrapa. (2016). Empresa Brasileira de Pesquisa Agropecuária. Girassol. Avaliable: https://www.embrapa.br/soja/cultivos/girassol. Acess: 01 jun. 2016.

Farias, S.G.G. et al. (2009). Efeitos dos estresses hídrico e salino na germinação de sementes de gliricídia. Caatinga, 22,152-157.

Ferreira, D.F. (2011). Sisvar: a computer statistical analysis system. Ciência e Agrotecnologia, 35,1039-1042.

Goldmann, I.L., Carter, T.E.J.R. \& Patterson, R.P. (1989). A detrimental interaction of subsoil aluminum and drought stress on the leaf water status of soybean. Agronomy Journal, 81,461-463.

Guedes, R.S. et al. (2013). Germinação e vigor de sementes de Apeiba tibourbou submetidas ao estresse hídrico e diferentes temperaturas. Ciência Florestal, 23,45-53.

Hoogenboom, G., Huck, M.G. \& Peterson, C.M. 1987. Root growth rate of soybean as affected by drought stress. Agronomy Journal, 79,697-614. 
Jaleel, C.A. et al. (2009). Drought stress in plants: A review on morphological characteristics and pigments composition. International Journal of Agriculture and Biology, 11,100-105.

Kappes, C. et al. (2010). Germinação, vigor de sementes e crescimento de plântulas de milho sob condições de déficit hídrico. Scientia Agricola, 11,125-134.

Krzyzanowski, F.C., França Neto, J.B. \& Costa, N.P. (2004). Teste do hipoclorito de sódio para semente de soja. Londrina: Embrapa Soja. (Embrapa Soja. Circular Técnica, 37).

Larcher, W. (2000). Ecofisiologia vegetal. São Carlos: Rima.

Machado Neto, N.B. et al. (2006). Deficiência hídrica induzida por diferentes agentes osmóticos na germinação e vigor de sementes de feijão. Revista Brasileira de Sementes, $28,142-148$.

Maraghni, M., Gorai, M. \& Neffati, M. (2010). Seed germination at different temperatures and water stress levels, and seedling emergence from different depths of Ziziphus lotus. South African Journal of Botany, 76,453-459.

Martins, C.C., Pereira, M.R.R. \& Lopes, M.T.G. (2014). Germinação de sementes de eucalipto sob estresse hídrico e salino. Bioscience Journal, 30,318-329.

Martins, C.C., Pereira, M.R.R. \& Marchi, S.R. (2011). Germinação de sementes de Melaleuca quinquenervia em condições de estresse hídrico e salino. Planta Daninha, 29,1-6.

Michel, B.E. \& Kaufmann, M.R. (1973). The osmotic potential of polyethylene glycol 6000. Plant Physiology, 51,914-916.

Muchow, R.C. (1982). Analysis of the effect of water stress on the growth of grain legumes. Brisbane: Csiro - Divixion of Tropical Corps and Pastures, $74 \mathrm{p}$.

Munns, R. (2002). Comparative physiology of salt and water stress. Plant, Cell and Environment, 25,239-250.

Oliveira Jr, R., Constantin. J. \& Inoue, M.H. (2011). Biologia e Manejo de Plantas Daninhas. Curitiba: Omnipax.

Paixão, C.L.D. et al. (2014). Caracterização fisiológica e bioquímica de genótipos de girassol com tolerância diferenciada ao estresse hídrico. Enciclopedia Biosfera, 10,2011-2022.

Pereira, M.R.R. et al. (2014). Estresse hídrico induzido por soluções de PEG e de $\mathrm{NaCl}$ na germinação de sementes de nabiça e fedegoso. Bioscience Journal, 30,687-696.

Queiroz, M.S. (2006). A experiência brasileira em biocombustíveis - Petrobras. In: Conferência e exposição bienal iniciativa do ar limpo nas cidades da América Latina. São Paulo, Palestra.

Ramos Junior, E.U. et al. (2013). Crescimento de plantas de cobertura sob déficit hídrico. Semina: Ciências Agrárias, 34,47-56.

Santos, V,D. et al. (1992). Efeito do estresse salino e hídrico na germinação e vigor de 
sementes de soja. Revista Brasileira de Sementes, 14, 189-194.

Scheidt da Rosa L. et al. (2005). Avaliação da germinação sob diferentes potenciais osmóticos e caracterização morfológica da semente e plântula de Ateleia glazioviana Baill (timbó). Cerne, 11,306-314.

Silva, L. M. M., Aguiar, I. B., \& Rodrigues, T. J. D. (2001). Seed germination of Bowdichia virgilioides Kunth, under water stress. Revista Brasileira de Engenharia Agrícola e Ambental, $5,115-118$.

Smith, C. W., \& Cothren, J. T. (1999). Cotton: Origin, history and production. New York: John Wiley e Sons.

Spollen, W. G., \& Sharp, R. E. (1991). Spatial distribution of turgor and root growth of low water potential. Plant Physiology, 96, 438-443.

Spyropoulos, C. G. (1986). Osmoregulation, growth and sucrose accumulation in germinated Trigonella foenulil (Fenugreek) seed treated with polyethylene glycol. Plant Physiology, 68, 129-135.

Taiz, L., \& Zeiger, R. (2009). Plant Physiology. California: The Benjamim/Commings Publishing Company, Inc.

Távora, F. J. A. F., \& Melo, F.I. (1991). Respostas de cultivares de amendoim a ciclos de deficiência hídrica: crescimento vegetativo, reprodutivo e relações hídricas. Ciência Agronomica, 22, 47-60.

Teixeira, R. N. et al. (2011). Germinação e vigor de sementes de crambe sob estresse hídrico. Irriga, 16, 42-51.

Torres, S. A., Vieira, E. L., \& Marcos Filho, J. (1999). Efeitos do estresse hídrico na germinação e no desenvolvimento de plântulas de pepino. Revista Brasileira de Sementes, 21, 59-63.

Vaz de Melo, A. et al. (2012). Germinação e vigor de sementes de milho-pipoca submetidas ao estresse térmico e hídrico. Bioscience Journal, 28, 687-695.

Yamashita, O. M. et al. 2009. Fatores ambientais sobre a germinação de Emilia sonchifolia. Planta Daninha, 27, 673-681.

\section{Copyright Disclaimer}

Copyright for this article is retained by the author(s), with first publication rights granted to the journal.

This is an open-access article distributed under the terms and conditions of the Creative Commons Attribution license (http://creativecommons.org/licenses/by/4.0/). 